\title{
Veloplagt og fornyende dansk litteraturhistorie
}

Anne-Marie Mai: Hvor litteraturen finder sted 1-3, København: Gyldendal, 2010-2011. Bind 1: Fra Guds tid til menneskets tid 1100-1800, 473 sider, pris: 399 kr; Bind 2: Længslens tidsaldre 1800-1900, 293 sider, pris: 399 kr; Bind 3: Moderne tider 1900-2010, 492 sider, pris: $399 \mathrm{kr}$.

Diskussionen kan begynde her

Væsentlige og nytænkende værker anmelder man ikke ved at give karakterer, men ved at diskutere med dem. Simpelthen fordi de ikke er færdige. Det er just derfor, de er væsentlige. I en vis forstand begynder de først på sidste side, og det man diskuterer og afprøver er, hvordan de næste sider kan se ud. Lidt ligesom med gode samtaler. De er gode, fordi man kan fortsætte dem, ikke fordi de er færdige.

Når værker er nytænkende, vil der jo være mangler og fejl. Ellers har de ikke tænkt nyt nok. Og det kan man så pille $\mathrm{i}$ - hier irrt sich ..... Men den slags ting er ikke interessante i sig selv. De kan klares med et rettelsesblad eller et nyt afsnit. Kun hvis skæverter afspejler nogle usynlige konsekvenser, produktive eller hæmmende, af den retning, værket angiver, og dermed bidrager til en diskussion, har de interesse. Dem vil jeg nævne et par af.

De to første bind af Anne-Marie Mais nye litteraturhistorie har ligget på mit skrivebord et stykke tid og ventet på sidste bind. Men jeg var ikke i tvivl om, at der her endelig kom en større samlet litteraturhistorie med et principielt sigte. Med andre ord: et væsentligt og nytænkende værk, der udfordrer til diskussion. Når jeg siger endelig, skyldes det, at det sidste samlede bud er uden principiel ambition, bortset fra de afsnit hvor nogle af de enkelte bidragydere selv tænker i nye baner: Dansk litteraturhistorie 1-5 (2006-2009) redigeret af Klaus P. Mortensen og May Schack. Man kunne frygte, at dette mammutværk ville lægge den principielle debat om litteraturskrivning død i Danmark år frem, hvis altså denne debat samtidig skal omsættes til praktisk litteraturhistorieskrivning i stort format. De økonomiske og menneskelige ressourcer kunne være brugt op i denne omgang. Her havde jeg glemt Anne-Marie Mai. Med hendes værk kan en væsentlig diskussion begynde igen.

\section{Uforløst dobbeltstruktur}

Lige et kort overblik først. Bogens centrale organiserende begreb er, som titlen siger, litteraturens steder. Dér hvor litteratur er skrevet og udvekslet, hvor forfattere og kunstnere har færdedes, hvor forbindelseslinjerne til samfundet som helhed er blevet trukket, og hvor verden omkring Danmark har sat sine spor og modtaget indtryk fra Danmark. Mai har valgt nogle få steder blandt flere mulige: middelalderens katedral, renæssancens herregårde og hof, oplysningstidens akademier, det 19. århundredes præstegårde og saloner, 
og det 20. århundredes bladhus, metropol og internet. Væsentlige steder, både for litteraturens historiske forandringer og kulturelle funktioner, ingen tvivl om det. Også for ændringer i opfattelsen af, hvad steder overhovedet er, heller ingen tvivl om det. Men der er ingen diskussion af, hvilke mulige steder der er valgt væk og hvorfor, og hvorfor der kun er ét sted pr. tidsafsnit.

Ud over nødvendige noter og en synoptisk tidstavle består hver af de tre bøger af ét eller flere dobbeltafsnit, hvert med en kronologisk fortælling og en stedsfortælling, én af hver. Og sidste bind rummer en mængde nyttige links (dog ikke UNESCOs søgemaskine for oversættelser mellem alverdens sprog, Index Translationum, der også rummer et særligt link til 'Literature and translation'). Desuden er der et indskudt teoretisk afsnit i andet bind (II. 212-239), sikkert anbragt dér så læseren kender den tekst, der teoretiseres over først, forudsat jo at læseren opfører sig pænt og læser bøgerne kronologisk. Men Mai vil nok prøve at undgå den kedelige fremstilling: først teori, så anvendelse. Det har Mai og jeg set nok af, og også, når sandheden skal frem, selv praktiseret nu og da.

Den ene del af hvert dobbeltafsnit, den korteste, er en kronologisk fremstilling af litteraturen i det tidsrum, bindet eller dele af bindet omfatter, fx 1900-1940. Den anden del er en stedsfortælling, hvor litteraturens historie fortælles i en vekselvirkning med de udvalgte steders historie og med udgangspunkt i et konkret sted, fx Ribe Domkirke, Sorø Akademi eller Politiken. Men samtidig sker der en udvidelse af disse steder til et mere alment begreb, fx herregården i renæssancekapitlet, hvor der er flere konkrete gårde på programmet, eller Dansk Presse med mange aviser i spil i afsnittet 1900-1940, hvor Politiken er det konkrete sted.

Denne dobbeltstruktur er ikke begrundet i forhold til det litterære sted som det principielle grundlag for fremstillingen, ja, så vidt jeg kan se, er den slet ikke eksplicit begrundet. Den er der bare, skønt forordet til bind 1 faktisk siger, at stederne erstatter kronologien. Er de kronologiske afsnit med for at gøre det lettere for dem, der er vant til den lineære kronologiske organisering? Skyldes de en usikkerhed på, om stedskonceptet og de valgte steder kan bære hele den litteraturhistoriske forpligtelse? Bogens komposition ser ud til at have et uforløst forhold til det spatiale grundkoncept. Jeg synes, Mai skulle tro på sit koncept for fuld musik i en konsekvent brug af stedet hele vejen igennem og gøre de tilvalg og fravalg synlige, der følger heraf, også hvor de måtte koste noget i forhold til aspekter, der ikke kan komme med i en sådan fremstilling. Nu fungerer den kronologiske fortælling som et opsamlingsheat for den litteratur, der deltager i turen fra sted til sted, og dobbeltstrukturen gør kriterierne for tilvalg og fravalg som følge af stedkonceptet usynlige og svækker fremstillingens principielle, nytænkende karakter.

\section{Flere slags steder}

Hvad stedet som kategori angår, bruges det både i en horisontal og i en vertikal forstand. For det første skifter stedets historiske betydning horisontalt op gennem tiden, og Mai forankrer det hos forskellige teoretikere i forskellige perioder, fx er Edward Caseys fænomenologiske stedsteori forankringspunkt for inddragelsen af renæssancens herregårde og også for det tidlige 20. århundredes bladhuse, mens fx Michel Foucaults heterotopi danner baggrund for brugen af katedralen som ramme om middelalderlitteraturen (II, 231ff; III, 393). Det er ganske vist ikke så let på ét ben og i klare vendinger at forklare forskelle og ligheder på alle de inddragne stedsbegreber: Hvordan adskiller Caseys al- 
mene fænomenologiske stedsbegreb sig grundlæggende fra Bakhtins romanspecifikke kronotop, der er nøglebegrebet for oplysningstidens sted, Akademiet? Manuel Castells netværkstænkning synes for mig måske mere oplagt til metropol og internet end Pierre Bourdieus feltteori og Søren Polds begreb 'det skriptede sted' i hans litterært-kulturelle medieteori.

Men Mai vil kun have én hovedteoretiker pr. sted, ligesom hun kun vil have ét sted pr. tidsafsnit. Differentieringerne virker i skemaform noget forcerede, og stedbegreberne er ikke helt på samme niveau: Polds og Bakhtins steder er medie- og genrespecifikke, mens andre som Caseys og Foucaults er langt mere generelle, mens Bourdieus feltbegreb igen peger på andre kontekster. I analyserne fungerer brugen af begreberne imidlertid udmærket, fordi Mai er god til at læse. Jeg tror ikke, at de læsere, der helt springer det korte teoriafsnit og det afsluttende skema over, vil gå vild i analyserne eller bemærke overgangene fra det ene spatiale nøglebegreb til det andet, når de kommer fra ét tidsafsnit til et andet. Begreberne sætter ikke specifikke og præcise spor, når fremstillingen ruller ned over siderne (måske bortset fra den afsluttende stedsfortælling om internettet, hvor Polds 'skriptede sted' direkte indgår).

Overfor denne horisontale dimension for stedernes og litteraturens foranderlighed står, for det andet, en vertikal dimension, ser det ud til, fx forholdet mellem den konkrete herregård, som Rosenkrantzernes Rosenholm, og Herregården som alment begreb. Dette sidste svarer til Max Webers brug af idealtyper, et begreb Mai kunne have haft glæde af. Idealtyper er abstraherede og generaliserede rammer, altså praktisk og ikke logisk definerede overbegreber, for konkrete menneskelige handlinger og relationer som bl.a. har inspireret Pierre Bourdieu, hvis feltbegreb Mai henviser til for det 20. århundredes metropol som litterært sted. Hos Mai er det stederne, der som idealtypiske formationer er ramme om litteratur som et sæt af handlinger med og om tekster.

Den horisontale dimension er klart diskuteret af Mai, mens den vertikale ikke er. Det kunne have været en god ide at gøre det, bl.a. fordi glidningen fra herregårdene til Herregården og tilbage igen, fra Sorø Akademi til Uddannelsesinstitution og tilbage igen i bredere almindelighed sker uden særlig markering. (I øvrigt er Sneedorffs detaljerede moderne reformtanker fra Den Patriotiske Tilskuer for de lærde skoler ikke omtalt, kun Holbergs korte principrefleksioner, selv om Sneedorff fortjent får en fyldig behandling). Et af de ikke-udtalte kriterier for valg af steder, dog antydet ved katedralen, er netop deres evne til at manifestere sig i konkrete steder og samtidig agere som idealtype. Den evne har ikke alle steder, hvor der er spændende litterære fortællinger at diske op med. Den konkrete virkelighed er genkendelig i idealtypen og omvendt, og de konkret beskrevne steder får dermed et bredt kulturelt perspektiv. Idealtypen kunne være med til mere præcist at begrunde valget af de konkrete steder på tværs af de historisk skiftende stedsbegreber.

\section{Sted, arkiv, fortælling}

Det virkeligt fremragende hos Mai er nu, at hun slår ned på nogle grundbegreber, der kan forene den teoretiske profilering, den kulturelle dialog og de pragmatiske tilpasninger til den litteratur, hun arbejder med. På den baggrund præsenterer Mai de tre overordnede begreber, der først og fremmest styrer fremstillingen: stedet, arkivet, fortællingen.

Steder er, som sagt, ikke entydigt fastlagte størrelser, men varierer selv med den historie, de artikulerer. Edward Caseys monumentale værker eksemplificerer denne grundtan- 
ke. Med internettet i den ene ende og katedralen i den anden er stedet som samlebegreb virkelig blevet strakt til det yderste, nogle vil måske sige over evne. Men denne smidighed er samtidig en afgørende forudsætning for, at bogen er væsentlig og læseværdig. Vi inviteres umiddelbart til en diskussion om begrebets rækkevidde. Samtidig er stedet grundlag for at fortælle og bevare fortællingen som kulturel relevant formidlingsform.

Og det er spændende og fængende historier, vi får, især om herregårde og hof, om præstegård og saloner, om bladhuset og om metropolen, der har New York i centrum. (Men Per Olsen og Christen Kold Thomsens artikelsamling om beat-generationen, Frigørelsens Hylen, 2004, er glemt). De er lige til at springe ud i uden om kronologi og teori. Valget af katedralen og internettet forekommer mig at give mere forudsigelige resultater. Men man er klar til at styrte sig over Birgitte Thotts papirer og Marie Bregendahls urimeligt marginaliserede forfatterskab og løse billet til The Big Apple.

Samtidig er stedet et pragmatisk stærkt fokuspunkt for læseren med smidige grænser for indlemmelse og udelukkelse af detaljer og for konkretisering af strømninger, ideer og tendenser. Læseren får nemt sin erfaring med ind i den historiske læsning.

Men jeg studser lidt over to ting. For det første at genren den topografiske tekst, typisk et digt, ikke får nogen plads (topos som retorisk begreb omtales). Når nu andre vidensog uddannelsesaspekter alligevel inddrages i afsnittet om akademiet - oplysningstidens sted - burde Videnskabernes Selskab fra 1742 nævnes og her især selskabets store topografiske projekt: kortlægningen af Danmark, foregrebet af Ole Rømers matrikel 100 år tidligere og Erik Pontoppidans danske atlas. Ikke mindst i lyset af hele den ændring af Danmark som sted, der sker med udskiftningen mellem ca. 1780 og 1820. Ja, hele landskabet som historisk foranderligt sted kunne have været et relevant sted (med masser af konkrete forankringsmuligheder), netop da det nationale landskab skæres ud af det skrumpende patriotiske, feudale og koloniale danske imperium og får enorm litteraturog kunsthistorisk betydning. Men eftersom fravalgskriterier ikke er nævnt, kun tilvalgskriterier, der begrunder, at de valgte steder er relevante, så er det svært at sige, hvorfor der er en lakune her.

Det bringer mig til det andet punkt. Det er kun steder $i$ Danmark, der er med, dvs. i det man kunne kalde Syddanmark, og ikke Danmark selv som sted med variable grænser og tilknyttede kolonier og territorier op gennem historien. Denne udeladelse er en indirekte tribut til den traditionelle nationale fortælling, som Mai ellers klart bryder med andre steder. Bevidstheden om kolonidanmark har fx været nærværende i Charlotte Schimmelmanns salon, der behandles grundigt i bind 1. Schimmelmænnernes generøse husholdning var jo finansieret af slaver og plantagedrift som så meget andet i det 18. århundredes Danmark. Grundtvig tog del i slavedebatten i nationalromantisk lys, og hans brødre tog til kolonierne ligesom Poul Martin Møller. 'Langt højere bjerge' sang de på vestindisk kaj i 1820, da Christen Pram drog til Caribien, og Grundtvig skændtes bittert med Meir Aron Goldschmidt om etnisk danskhed.

Forfattere som Haldor Laxness og William Heinesen er ikke omtalt (Heinesen dog i et citat), selv om Island var, og Færøerne er dele af rigsfællesskabet, og selv om sprog- og litteraturkampen siden reformationen de to steder over for dansk er fuldt så kolonial og post-kolonial som den prosa, der nævnes af Jakob Ejersbo. Men fremmede steder i bredere forstand har været vigtige undervejs i dansk litteraturhistorie - det 19. århundredes Italiensfascination er ét vigtigt eksempel, og New York, som Mai originalt bruger som 
sted for tidsrummet 1940-1970, et andet. Også Syddanmark som et fremmed sted: Men indvandrerforfattere er næsten ikke omtalt (Maria Giacobbe, Janina Katz, Iboja WandallHolm, Efie Beydin og andre mangler). Måske er kolonien og eksilet for snævre til at fungere som brugbare steder, men det fremmede sted - som man godt kunne finde konkrete eksempler på - kan godt. Og de stedmoderligt behandlede rejseberetninger i dansk litteratur og også oversættelser kunne få en mere prominent plads.

Som svar på sådanne forbehold kunne man foreslå at inddrage flere steder end de få, der er inddraget, og mere end ét pr. tidsafsnit. Man kunne herigennem få et mere reelt billede af den historiske kontekst, især når steder er i konflikt (på fransk er modsætningen mellem la ville og la cour en gammel litteraturhistorisk sag, centrum og periferi en anden modsætning som post-koloniale studier har sat ekstra fokus på, cf. Oluf Friis' bog om Jylland i dansk litteratur fra 1929.) Ganske vist samler de kronologiske fortællinger nogle af sådanne stedsformationer op en gang imellem, som fx Blicher i den jyske udkant, men så netop uden fokus på stedernes principielle rolle.

Men måske ligger sådanne kriterier i Mais overbegreb, det andet grundbegreb, arkivet, med inspiration fra Michel Foucault og Paul Ricœur (II, 231). De valgte steder er arkiver, fordi de rummer spor af de litterære aktiviteter, hvorigennem litterære tekster bliver til, bliver brugt, bliver samlet, oversat, kanoniseret, distribueret osv. Og disse spor omfatter alle de aktiviteter og faktorer, der bestemmer litteraturens betydning og funktion i den bredest mulige danske, historiske kontekst, herunder også de koder og konventioner, der regulerer litteraturens liv i denne historiske kontekst - hvad dukker op, hvad glider ud, hvad får højstatus, hvad skraber bunden. Kolonien alene kan næppe fungere som arkiv på den måde, men omvendt burde kolonien være en del af arkivet de steder, der faktisk udvælges.

Så til Mais sidste grundbegreb, fortællingen. Som hos Ricœur er det den fremstillingsform, der skaber en effektiv og forståelig sammenhæng og forankrer betydning i forhold til liv og sted. Men den må ikke stivne som én stor fortælling om Danmark og dansk litteratur, slet ikke en teleologisk fortælling som i den traditionelle nationale dannelsesroman, der blev den grundform, litteraturhistorieskrivningen har arvet fra det 19. århundredes genreskabende litteraturhistorier. Denne er sværere at slippe af med end ismer og 10 års-inddelinger, eller endnu værre: underinddelinger som senfirsere, midthalvfemsere eller lignende vås. Problemet er ikke kronologien i sig selv. Den findes jo og er et nyttigt redskab. Men den må ikke laves om til ideologi ved at fyldes med teleologi, dannelseskoncepter og lineære darwinistiske udviklingsforestillinger, som det er sket gennem de sidste par 100 års litteraturhistorier. Det gør Mai klart op med.

Men de kronologiske fortællingers samlende begreber rummer en anden type litteraturhistorisk fortælling: avantgarde- eller gennembrudslitteraturhistorien. I bind tre er det 'det formelle gennembrud', der karakteriserer den blandede gruppe unge forfattere; bind to bruger Georg Brandes' reklamebegreb 'det moderne gennembrud' (der jo skulle virke lidt ligesom senere 'modernismens tredje fase'), og også det 19. århundredes første halvdel ses primært som en serie gennembrud.

Heroverfor lægger stedsfortællingerne mere op til tværgående samtidighed mellem forskellige positioner og relationer mellem steder inden for samme stedlige idealtype, hvad Mai selv i et vist omfang fremhæver i forbindelse med det 19. århundredes første halvdel og andre steder i de kronologiske afsnit. Fra den synsvinkel skal man også se på 
de positioner, der blot fortsætter fra tidligere perioder og måske er stærkere i det litterære miljø end gennembruddene. Det gælder således oplysningsmanden Knud Lyhne Rahbeks position i forhold til de mange romantiske unge. Jeg er ikke i tvivl om, at Mais hjerte ligger i stedsfortællingernes relationer mellem positioner og bevægelserne imellem dem, mere end i de isolerede gennembruds pædagogiske klarhed. Nogle af de kronologiske afsnit består i hvert fald sine steder af lidt pligtagtige korte beskrivelser af værker, titler og forfattere.

Dobbeltstrukturen med kronologiske fortællinger og stedsfortællinger slører bogens budskab om stedernes betydning, og er den måske udtryk for lidt usikkerhed over for, hvor meget stedsfortællingen kan bære?

\section{Nye læsemuligheder}

Min anmeldelse har mest beskæftiget sig med, hvordan Mais projekt er tænkt og udført, og hvordan det kan sætte skub i nytænkning. Det er jo ikke helt retfærdigt: Jeg glemmer alle de gode iagttagelser, de nye tekster og forfattere, den medrivende fremstilling, der er både strengt faglig og personlig. Og billedmaterialet, der får én til at springe i bilen og køre til Ribe eller Rosenholm igen. Det er et værk, der kan læses i bidder eller i store træk. Som kræver pauser, når man tager et ekstra kig på gamle kendinge fra dansk litteratur fra en ny vinkel, eller giver rynkede bryn, når man er uenig. Mais sidste ord lyder: "Stedsfremstillingen giver forfatterskaber og tekster ny fascinationskraft og åbner læsemuligheder." Det har du ret i. Men du skal selv tro på det.

Anmeldt af Svend Erik Larsen

\section{Romantiske lyksalighedsøer}

Gunilla Hermansson: Lyksalighedens øer. Møder mellem poesi, religion og erotik $i$ dansk og svensk romantik, Göteborg: Makadam Förlag, 2010. 397 sider, illustreret.

Lycksalighetens $O ̈$ er titlen på et eventyrdrama på vers forfattet af den svenske romantiske digter P.D.A. Atterbom. En ung konge ved navn Astolf fra det højeste nord bliver under en jagt væk fra sit selskab og søger ly for natten i, hvad der viser sig at være vindenes hule. Fra vestenvinden hører han om Lyksalighedens $\emptyset$ og dens underskønne herskerinde, Felicia. Astolf gribes af længsel, for han har selv i sine drømme set den skønne, og han beder vestenvinden om at føre ham til øen, hvor den evige ungdoms kilde springer. Hans ønske bliver bønhørt, og som den første mand betræder Astolf dette rent feminine paradis. Lyksalighedens $\varnothing$ har sine egne sagnfortællinger - om livet blandt mennesker, om strid og død, men også om kærligheden mellem mand og kvinde. Med Astolfs ankomst bliver sagnet om den erotiske kærlighed til virkelighed. I Felicias favntag glemmer Astolf sit tidligere liv, sine kongelige pligter og sin jordiske fæstemø Svanvit. Sådan henrinder tre år- 